\title{
Evaluation of the content and safety of nitrite utilisation in meat products in Serbia in the period 2016-2018
}

\author{
Aleksandar Bajcic', Radivoj Petronijevic *l, Nenad Katanic², Dejana Trbovic ${ }^{1}$, Nikola Betic ${ }^{1}$, \\ Aleksandra Nikolic ${ }^{1}$, Lazar Milojevic ${ }^{1}$
}

A b s tr a c t: Nitrites are inorganic salts widespread in water, fruits, vegetables, meat and meat products. Application of nitrites in the meat industry is necessary for multiple reasons. They suppress development of some microorganisms in food and are a source of nitrogen oxide that is widely involved in physiological functions of metabolism, food intake and energy balance. On the other hand, nitrites in food can produce nitrosamines that increase the risk of cancer. During regular quality control in 2016-2018, 972 samples of meat products were analysed and verified for compliance with regulations concerning nitrite levels, and the average participation of these meat products in daily intake of nitrite was estimated. The amount of nitrites in the examined meat products was within the permitted limits. The daily intake of nitrite in Serbia from meat and meat products was estimated as being from $0.015-0.020 \mathrm{mg} \mathrm{kg-1}$ body weight, which is below the limit values set by EFSA for safe daily intake, i.e. 0.06-0.07 $\mathrm{mg} \mathrm{kg}^{-1}$ body weight.

Keywords: nitrites, nitrates, meat products, consumer health, statistical evaluation, acceptable daily intake.

\section{Introduction}

In everyday human nutrition, the presence of nitrates, nitrites and nitrosamines in food is inevitable. These compounds are widespread in water, fruits, vegetables, and meat and meat products. This group of chemicals has multiple, necessary roles in the meat industry. From the bacteriological point of view, nitrite has an inhibitory role in the growth of microorganisms. This is of great importance in preventing the growth of surviving resistant microorganisms after commercial sterilisation processing to manufacture canned meat products (Codex Alimentarius Commission, 2016). Due to the antioxidant effect of nitrites, they are also used as preservatives (Govari and Pexara, 2015). Nitrates and nitrites are used in cooked and boiled sausages, fermented sausages, cured and smoked meat products etc. (Ducic et al., 2017). The technological significance of their use in meat processing is that they provide an adequate red colour for the meat, give a characteristic aroma to cured meat, and have bacteriostatic and bactericidal effects (Parthasarathy and Bryan, 2012).

Regarding human health, the use of nitrites in the meat industry has both positive and negative aspects. A positive effect of nitrites in food is that they participate in the suppression of some microorganisms and so can prevent foodborne diseases. Nitrites are also a source of nitrogen oxide, which has significant participation in the physiology of metabolism, food intake and energy balance. Also on the positive side of the use of nitrates and nitrites are the numerous beneficial effects for metabolic and cardiovascular health (Bedale et al., 2016). On the other hand, the negative effect on human health is the possibility of compounds forming that increase the risk of cancer (Parvizishad et al., 2017). When we consume nitrates and nitrites from fruits and vegetables, numerous protective compounds are also ingested that prevent the negative effects of nitrites on the human body. In meat products, though, these protective compounds are not present, which increases the risk to consumers' health. Therefore, nitrite use is regulated and legally permitted quantities are specified for application in the meat industry.

This research included several tasks and goals. Importantly, the nitrite content in meat products was analysed to assess compliance with legislation. In addition, on the basis of the obtained data, the real contribution of nitrites in meat products to the total daily intake (DI) of nitrites in Serbia was evaluated. Particular attention regarding the impact on consumer health was paid to semi-prepared products and products that are subsequently thermally 
treated, such as minced meat, bacon, cooked sausages and canned meats, and which are used for frying, in pizzas, and in frozen and grilled products.

\section{Materials and methods}

All chemicals and standards used in the study were analytical grade. The content of nitrite in meat products was determined using the reference method (ISO, 1999).

\section{Meat products and sample preparation}

Meat products ( $\mathrm{n}=972$ ) were produced locally or imported. The meats were classified as smoked meats, fermented sausages, cooked sausages, ready-to-eat and fully cooked meat meals, canned meats, cooked sausages, semi-prepared minced meats, bacon, or cured meats, and their contents of nitrites were measured. All products were examined as part of regular quality control of meat products or on request.

Sample preparation for nitrite determination was in accordance with the procedure described in the reference method (ISO, 1999).

\section{Statistical analysis}

Data was processed using common statistical analytical techniques. MS Office Excel software with Data Analysis Tool Pack was used to compile data and for statistical processing.

\section{Results and discussion}

\section{Meat products}

The study was conducted on 972 samples of meat products in Serbia: fermented sausages, boiled or cooked sausages, canned, smoked, semi-prepared minced or cured meats, ready-to-eat and fully cooked meat meals and bacon. In all of these products, except for semi-prepared minced meat products, the use of nitrite was regulated (Official Gazette of RS, 2015; Official Gazette of RS, 2013). Figure 1 shows the number of samples analysed per group of products.

The largest number of samples (314) was in the group of cooked sausages, which accounted for almost one third of the total number of meat products.

\section{Meat products}

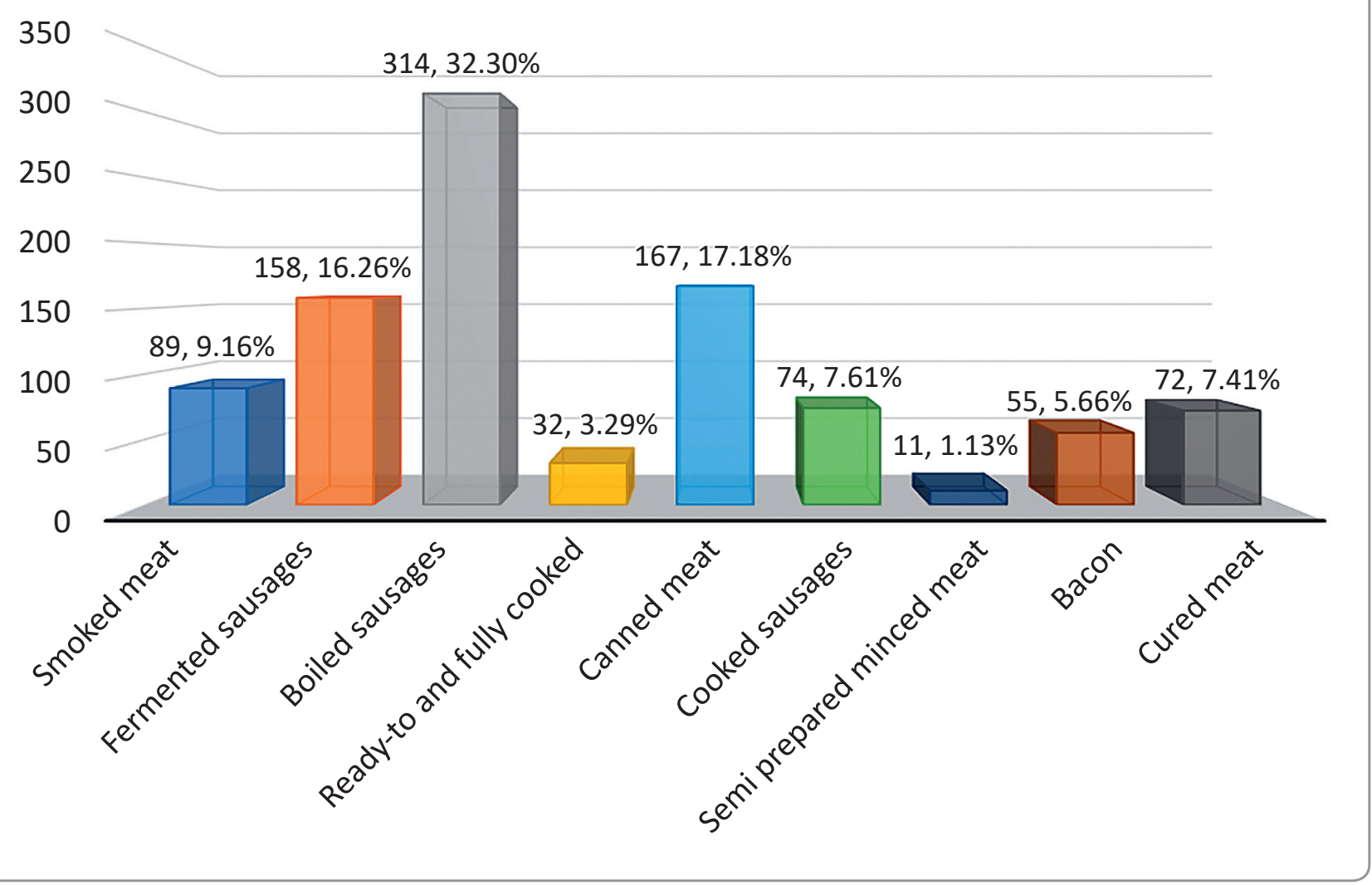

Figure 1. Number and percentage of meat products categorised in the nitrite content survey. 
The high number of cooked sausages tested can be explained by the high consumption of cooked sausages, which, of course, directly affects the amounts of locally produced and imported cooked sausages available in Serbia. The second largest groups were fermented sausages and canned meat (16-18\%). The third group included smoked meat products, cooked sausages, cured products and bacon (5-10\%). Ready-to-eat and fully cooked meat meals and semi-prepared minced meat products accounted for $<5 \%$ of meat products examined. Generally speaking, the distribution of the meat products tested was in direct proportion to their consumption levels in Serbia. The only exception was semi-prepared minced meat products, because their actual consumption level is far greater than their proportionate participation in this study. Their small number is due to the fact that nitrites are not specifically regulated in these products (Official Gazette of RS, 2015), and examination of their nitrite content is not covered by quality control of semi-finished products, but these analyses are performed occasionally and only on request.

\section{Nitrite content}

The average, minimum and maximum nitrite contents $\left(\mathrm{mg} \mathrm{kg}^{-1}\right)$ in the meat products are shown in Table 1.

The highest levels of nitrite were found in cooked sausages, canned and smoked meats and bacon. Given the preparation technology of these products, such values were expected. The lowest nitrite levels were determined in fermented sausages, ready-to-eat and fully cooked meals and semi-prepared minced meat products. The reasons for the low content of nitrite are different for each of these three product groups. In fermented sausages, the content of nitrite decreases during the ripening of sausages as a result of the process that takes place in the sausage. In meat meals, the nitrite originates mainly from added meats (sausage, bacon, etc.) that are among the many ingredients in the meals, and, therefore, their contribution to the nitrite content in the meals is low. In the semi-prepared minced meat, it is common to use ordinary salt $(\mathrm{NaCl})$ instead of nitrite salt. The average nitrite content ranged from $10-15 \mathrm{mg} \mathrm{kg}^{-1}$ in cooked sausages and cured meat products.

Statistical distributions of nitrite levels within the meat product groups differed. In the canned meats and cooked sausages, nitrite levels were normally distributed, while for other products, the distributions were log-normal or exponential. The distribution of nitrite levels was not examined for semi-prepared minced meat products because the number of tested samples in that group was insufficient for reliable statistical processing. The indicated distribution of test results is related to the stability of the nitrite content in the different meat products and is the consequence of their differing preparation and processing methods. In the case of products with thermal treatment, the decrease of nitrite content is slower than in the case of cured, smoked or fermented products. Reduction of nitrite content is particularly significant in fermented sausages where the main process is nitrite conversion into nitrates in the weak acid environment. Therefore, in fermented sausages, the presence of nitrite becomes latent

Table 1. Nitrite content in the examined categories of meat products

\begin{tabular}{lccccc}
\hline Meat product & $\begin{array}{c}\text { No. of } \\
\text { samples }\end{array}$ & $\begin{array}{c}\text { Average } \\
\text { content } \\
\left(\mathbf{m g ~ k g}^{-1}\right)\end{array}$ & $\begin{array}{c}\text { Minimum } \\
\text { content } \\
\left(\mathbf{m g ~ k g}^{-1}\right)\end{array}$ & $\begin{array}{c}\text { Maximum } \\
\text { content } \\
\left(\mathbf{m g ~ k g}^{-1}\right)\end{array}$ & $\begin{array}{c}\text { Maximum } \\
\text { permitted } \\
\text { limit }\left(\mathbf{m g ~ k g}^{-1}\right)\end{array}$ \\
\hline Smoked meats & 89 & 24.89 & 0 & 120.98 & 150 \\
$\begin{array}{l}\text { Fermented sausages } \\
\text { Cooked sausages }\end{array}$ & 158 & 0.65 & 0 & 7.54 & 150 \\
$\begin{array}{l}\text { Ready-to-eat and } \\
\text { fully cooked }\end{array}$ & 314 & 36.60 & 0 & 111.7 & 150 \\
$\begin{array}{l}\text { Canned meats } \\
\text { Cooked sausages }\end{array}$ & 167 & 0.48 & 0 & 4.34 & 150 \\
$\begin{array}{l}\text { Semi-prepared } \\
\text { minced meats }\end{array}$ & 11 & 35.96 & 0 & 87.58 & 100 \\
$\begin{array}{l}\text { Bacon } \\
\text { Cured meats }\end{array}$ & 12.49 & 0 & 89.59 & 150 \\
\hline
\end{tabular}


because the process is reversible and nitrates can, under certain conditions, be recovered into nitrites (Zivkovic and Stajic, 2016). Additionally, nitrite levels were measured in 972 meat samples, which is an indication of the reliability of the results and conclusions obtained by statistical processing.

A graphical representation of the data on the nitrite content of the meat product groups is given in Figure 2.

\section{Compliance with legislation}

The content of nitrites in meat products, i.e. quantities added to the products in order that they are safe for use in human nutrition, is closely related to process hygiene. When hygiene of meat production and processing facilities is improved, the possibility of adding less nitrite to meat products is increased, and by extension, the meat/food produced is likely safer. Compliance with legal regulations and information on the real content of nitrites in meat products, among other parameters, indirectly points to the implementation of good manufacturing practice and a Hazard Analysis and Critical Control Point system (Tomasevic et al., 2017).
In the current research, no samples of meat and meat products with nitrite content greater than permitted values (Official Gazette of RS, 2013) were detected. In the case of semi-prepared minced meat products, nitrite $\left(9.78 \mathrm{mg} \mathrm{kg}^{-1}\right)$ was detected in one sample. For these products, the quantity of nitrite is not regulated (Official Gazette of RS, 2013), and moreover, the current regulation for meat and meat products (Official Gazette of RS, 2015) does not allow the presence of nitrites in these products.

\section{Meat product consumption and estimation of nitrite DI in Serbia}

The average monthly consumption of different types of food per household in Serbia during 2016 is shown in Figure 3 (Bulletin, Household budget survey, 2016).

The data show that in Serbia, monthly, meat and meat products are consumed more than all foodstuffs listed, almost twice as much as milk, cheese and eggs or bread and cereals. The data illustrate the importance of the intake of nutrients, but also additives, salts and other ingredients, through meat and meat products.

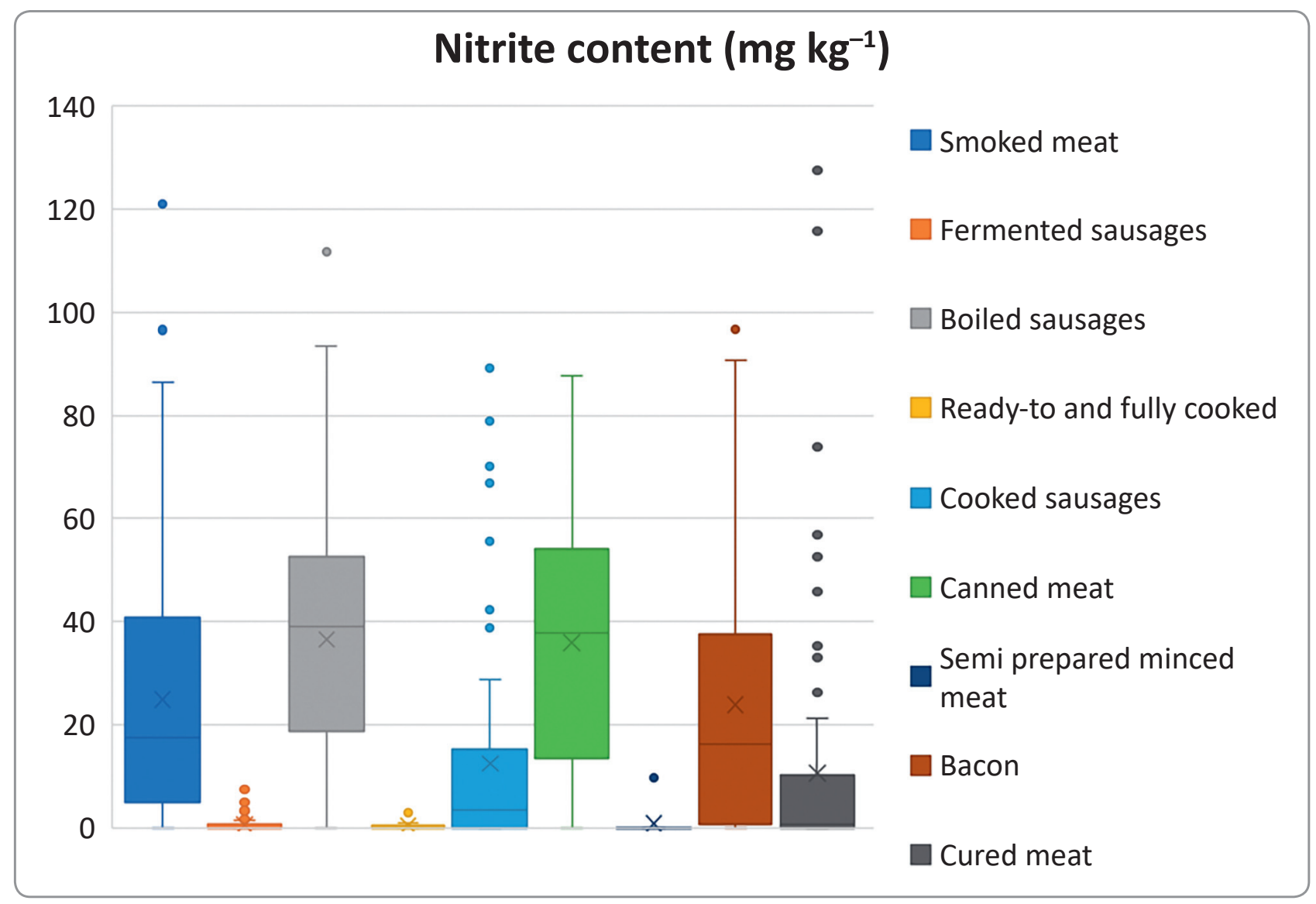

Figure 2. Nitrite content $\left(\mathrm{mg} \mathrm{kg}^{-1}\right)$ in the examined meat products 


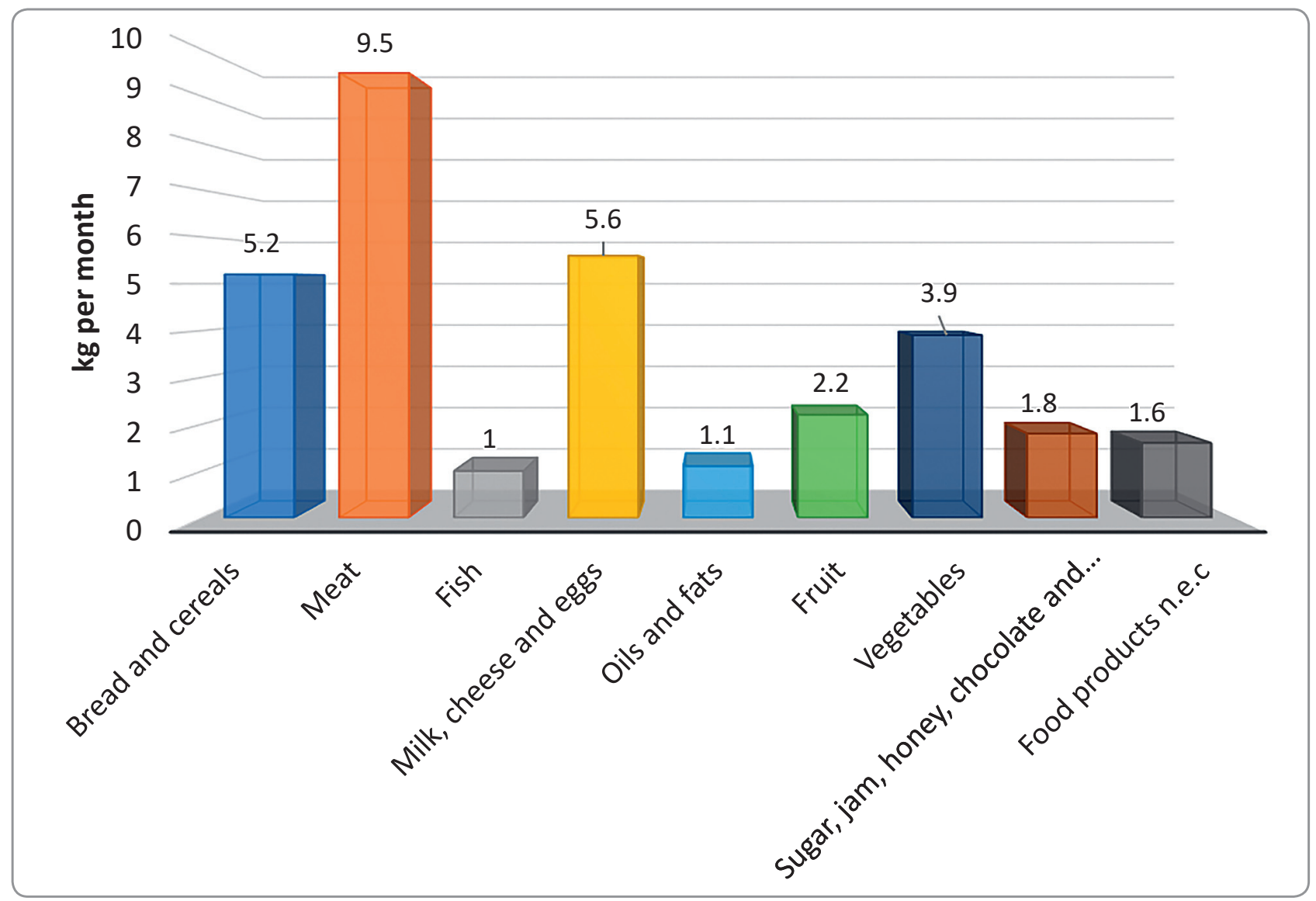

Figure 3. Average monthly food consumption (kg per month) per household in Serbia

On an annual basis, the consumption of meat products per household is almost equal to the consumption of pork and poultry meat, which are the most important categories of meat consumed in Serbia (Figure 4). The average DI of nitrite in Serbia via meat products can be roughly estimated using data on nitrite content in meat products as well as data on consumption of dried meat and meat products. The calculation used the average number of household members for 2016 of 2.88 inhabitants per household (Bulletin, Household budget survey, 2016):

$$
\begin{gathered}
\mathrm{DI}=(0.092 \cdot 24.89 \mathrm{mg} \mathrm{kg}+0.163 \cdot 0.65 \mathrm{mg} \\
\mathrm{kg}^{-1}+0.323 \cdot 36.60 \mathrm{mg} \mathrm{kg}+0.033 \cdot 0.48 \mathrm{mg} \\
\mathrm{kg}^{-1}+0.172 \cdot 35.96 \mathrm{mg} \mathrm{kg}+0.076 \cdot 12.49 \mathrm{mg} \\
\mathrm{kg}^{-1}+0.057 \cdot 23.95 \mathrm{mg} \mathrm{kg}+0.074 \cdot 10.72 \mathrm{mg} \\
\left.\mathrm{kg}^{-1}\right) \cdot(39.1 \mathrm{~kg} \text { year }+15.6 \mathrm{~kg} \text { year } \\
(365 \text { days year-1 } \\
\text { (1) } 2.88 \text { inhabitants per household }) \\
\quad=1.22 \mathrm{mg} \text { nitrite daily per capita. }
\end{gathered}
$$

There is no data on the average body weight (b.w.) of the Serbian population in recent literature. If it is assumed that the average body weight is between 60 and $80 \mathrm{~kg}$, DIs of $0.015-0.020 \mathrm{mg} \mathrm{kg}^{-1}$ b.w. are obtained. These values are far below the acceptable daily intake (ADI) of $3.7 \mathrm{mg} \mathrm{kg}^{-1}$ b.w. according to EFSA recommendations, and below the safe level of DI of $0.07 \mathrm{mg} \mathrm{kg}^{-1}$ b.w. (EFSA, 2017). However, these nitrite consumption levels originating from meat and meat products contribute about $1 / 4$ to $1 / 3$ of the safe level of nitrite DI, especially when a more conservative ADI value of $0.06 \mathrm{mg}$ $\mathrm{kg}^{-1}$ b.w. (EFSA, 2017) is considered. It should be noted that the calculated intake levels are only part of the DI of nitrite, and that other foods contribute to a higher intake, especially leafy vegetables, etc.

\section{Health risks}

As a result of the development of the meat industry and its need to adapt to consumers by offering attractive products with longer shelf lives, new tastes, and so on, many food additives have been used, and one of most significant roles belongs to nitrites. A series of studies was conducted to determine possible positive or negative effects of nitrite on human health (Sindelar and Milkowski, 2012). In addition to inducing antimicrobial effects, preventing the oxidation of lipids and achieving the appropriate aroma and colour in meat products, nitrites also have effects on the human body. Numerous studies highlight 


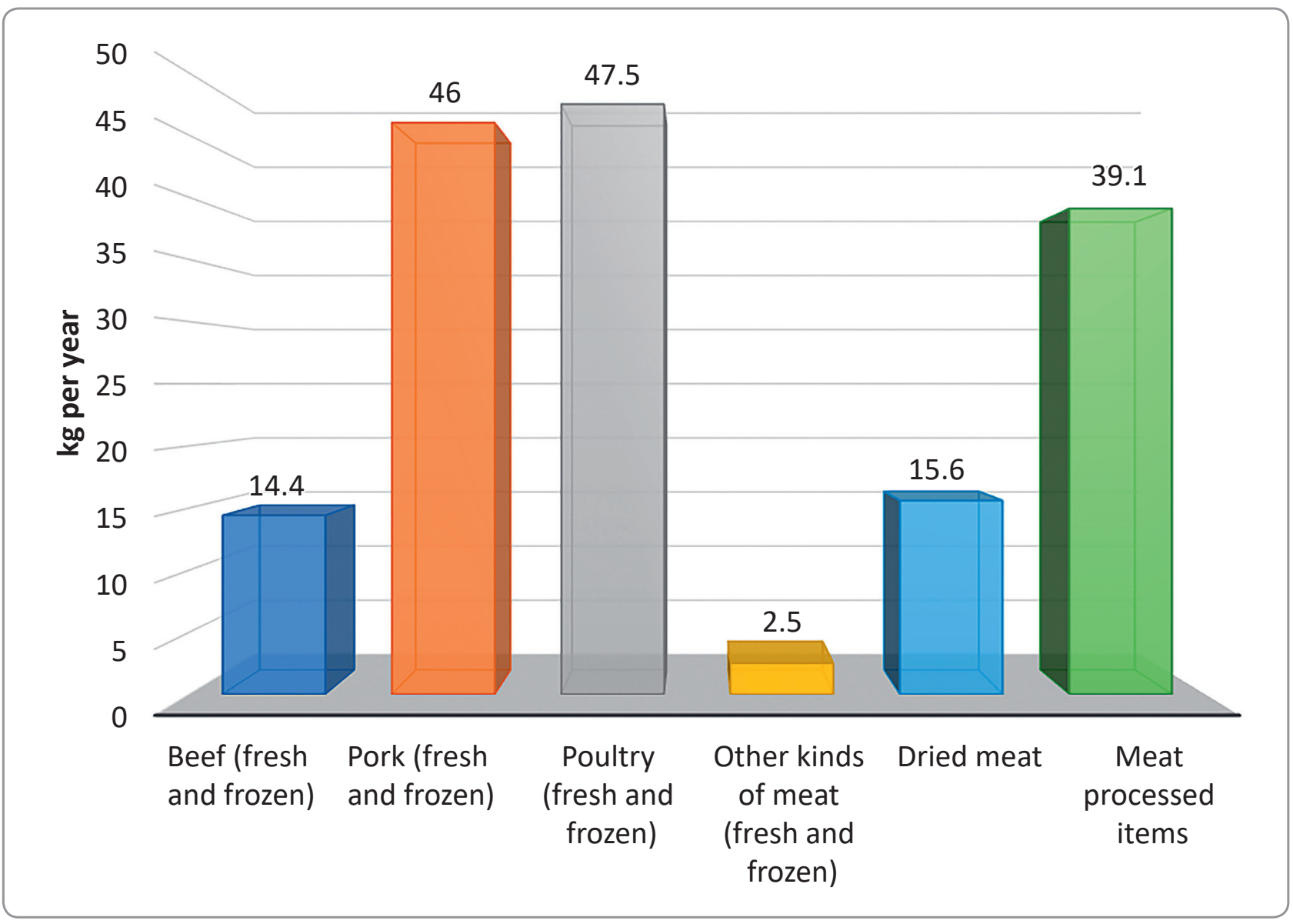

Figure 4. Average annual meat and meat products consumption $(\mathrm{kg})$ per household in Serbia

the beneficial contribution to the physiological functions of metabolism, food intake and energy balance. However, other studies indicate use of nitrites and their involvement in a number of metabolic processes result in the formation of carcinogenic compounds (Lammarino et al., 2013). Nitrosamines, carcinogenic compounds resulting from the use of added nitrates and nitrites, can also be formed from naturally occurring nitrates and nitrites in food. It is, therefore, necessary to add them to meat products in as little as possible amounts that are still technologically effective (Codex Alimentarius Commission, 2018). Large amounts of these compounds in the body contribute to the development of cancer in gastrointestinal tract organs, the most commonly affected being colon, rectum, liver, thyroid and stomach (Kobayashi, 2018). The substances themselves do not directly affect the development of cancer, but they promote its proliferation and so are classified as risk factors.

Health risks increase if nitrite content in meat products exceeds the permitted limits. Studies have shown that use of nitrates and nitrites in appropriate doses may prevent or slow down the onset of some diseases (Bryan and Ivy, 2015). Risks, though, are particularly increased in people with hypertension, coronary, heart disease, obesity or metabolic disorders (Ghasemi and Jeddi, 2017). The current study in Serbia on meat and meat products sampled between 2016 and 2018 found the amount of nitrite in these foods was under the allowed limits (except for one sample). In addition, important information from a health perspective is that the DI of nitrite derived from meat products is relatively low, below the recommended ADI (EFSA, 2017).

However, particular care must be taken when drawing conclusions, since consideration should also be given to the specificity of the chemical behaviour of nitrite in certain groups of meat products, the technological process of production and any subsequent thermal treatment of these products. Under appropriate conditions, nitrosamines, which are carcinogenic, can occur at elevated temperatures. Also, nitrite alone does not directly affect the production of cancer, but it promotes the proliferation and malignant transformation of tumour cells (Pengyan et al., 2018).

The presence of added nitrites in semi-prepared minced meat products was, in comparison with the other tested products, perhaps the greatest risk to 
consumer safety. In Serbia, traditional minced meat products prepared by grilling or barbecuing at high temperatures are one of the most frequently consumed fast foods. Nitrites are added to these products to maintain a fresh meat colour. On several occasions, unauthorised addition of metabisulphite for microbiological preservation was established in these products (Koricanac et al., 2017). The probability of reactions involving nitrites and the formation of compounds potentially harmful to consumer health increases with the combined action of metabisulphites that influence the reduction of $\mathrm{pH}$ and thermal treatment at high temperatures. However, an insufficient number of these products has been analysed to allow a clear conclusion on the level of consumer vulnerability. A more extensive study to determine the content of nitrites, as well as bisulphite, expressed as $\mathrm{SO}_{2}$ content, would show the real state of the presence of these compounds. This would be a good basis for assessing the potential risks to the health of consumers in Serbia, as well as for regulating the unauthorised use of these additives.

\section{Conclusion}

The nitrite content was measured in 972 samples of meat products in Serbia. The representation of the product groups in our complete population of analysed products reflected their demand and consumption in Serbia. Among our product groups, the highest consumption levels were of thermally treated products such as cooked sausages and canned meats, suggesting that cheaper products with prolonged shelf lives are the most common choice of consumers.

We found the consumption of nitrite via meat products in Serbia is below the safe level. This conclusion, however, should be taken with reserve because, in the absence of official statistical data related to the biometric parameters of the population in Serbia, likely DIs of nitrite were calculated within the boundaries we determined. The results of the assessment of DI are, therefore, indicative, not final. Meat and meat products are not the only source of nitrites, but consumption of these products is widespread among the Serbian population, and therefore, the contribution meat makes to consumer nitrite intake must be taken into consideration. The addition of nitrites to semi-prepared minced meat products, which are the most common form of fast food besides piz$\mathrm{za}$, is a potential risk factor. It is necessary, on the one hand, to increase public awareness of the health risk of nitrite/nitrate use, and on the other hand, to conduct suitable controls on meat products, including on the popular semi-prepared minced meat products that are not covered by regular quality control or legislation (Koricanac et al., 2017; Janjic et al., 2015).

\title{
Evaluacija sadržaja i bezbednosti upotrebe nitrita u proizvodima od mesa u Srbiji u periodu 2016-2018
}

\author{
Aleksandar Bajčić, Radivoj Petronijević, Nenad Katanić, Dejana Trbović, Nikola Betić, Aleksandra Nikolić, \\ Lazar Milojević
}

A p s tr a kt: Nitriti su neorganske soli široko rasprostranjene u vodi, voću, povrću, mesu i proizvodima od mesa. Njihova primena u industriji mesa je višsestruka i neophodna. Pozitivno utiču na suzbijanje razvoja određenih mikroorganizama u hrani i predstavljaju rezervoar azot oksida koji ima široku primenu u fiziološkoj funkciji metabolizma, unosa hrane i energetskog bilansa. Sa druge strane, mogući su uzročnici nastanka kancerogenih nitrozamina koji povećavaju rizik od nastanka raka. Ispitano je 972 uzorka proizvoda od mesa u toku redovne provere kvaliteta u periodu od 2016-2018 godine, proverena usaglašenost sa zakonskom regulativom i procenjeno prosečno učešće proizvoda od mesa u dnevnom unosu nitrita. Sadržaj nitrita u proizvodima od mesa u kojima je sadržaj regulisan je bio u granicama dozvoljenog. Procenjeno je da se dnevni unos nitrita u Srbiji kreće u granicama od 0.015-0.020 mg kg-1 telesne mase, što je ispod graničnih vrenosti koje je postavila EFSA za nivo bezbednog dnevnog unosa od 0.06- $07 \mathrm{mg} \mathrm{kg}^{-1}$ telesne mase.

Ključne reči: nitriti, nitrati, proizvodi od mesa, zdravlje potrošača, statistička procena, prihvatliivi dnevni unos.

Disclosure statement: No potential conflict of interest was reported by authors.

Acknowledgements: The results presented in this paper were based on the research realised within the project III46009 Ministry of Education, Science and Technological Development of Serbia. 


\section{References}

Bedale, W., Sindelar, J. J. \& Milkowski, L.A. (2016). Dietary nitrate and nitrite: Benefits, risks, and evolving perceptions. Meat Science, 120, 85-92.

Bryan, S. N. \& Ivy, L. J. (2015). Inorganic nitrite and nitrate: evidence to support consideration as dietary nutrients. $\mathrm{Nu}$ trition Research, 35 (8), 643-654.

Bulletin Household budget survey. (2016). available online: http://publikacije.stat.gov.rs/G2016/PdfE/G20165611.pdf

Codex Alimentarius Commission (2016). Discussion paper on the use of nitrates (INS 251, 252) and nitrites (INS 249, 250). CX/FA 17/49/11 December 2016.

Codex Alimentarius Commission (2018). Discussion paper on the use of nitrates (INS 251, 252) and nitrites (INS 249, 250). CX/FA 18/50/9 February 2018.

Ducic, M., Polak, T., Lusnic Polak, M., Demsar, L., Vranic, D. \& Baltic, M. Z. (2017). Effect of sodium nitrite and heat treatment on cholesterol oxidation products and sensorial characteristics of dry fermented sausages. Meat Technology, 58 (2), 110-117.

EFSA - European Food Safety Authority. (2017). Re-evaluation of potassium nitrite (E 249) and sodium nitrite (E 250) as food additives. EFSA Journal, 15 (6), 4786.

Ghasemi, A. \& Jeddi, S. (2017). Anti-obesity and anti-diabetic effects of nitrate and nitrite. Nitric Oxide, 70 (1), 9-24.

Govari, M. \& Pexara, A. (2015). Nitrates and Nitrites in meat products. Journal of the Hellenic Veterinary Medical Society, 66 (3), 127-140.

Janjic, J., Lovrenovic, M., Grujic, R., Ivanovic, J., Boskovic, M., Sarcevic, D., Glisic, M., \& Baltic, Z. M. (2015). Fast food in adolescents' diet. Meat Technology, 56 (2), $154-160$

Kobayashi, J. (2018). Effect of diet and gut environment on the gastrointestinal formation of $\mathrm{N}$ - nitroso compounds: A review. Nitric Oxide, 73, 66-73.

Koricanac, V., Vranic, D., Trbovic, D., Petronijevic, R. \& Parunovic N. (2017). Presence of sulphites in different types of partly processed meat products prepared for grilling.
IOP Conf. Series: Earth and Environmental Science, 85 012067 doi :10.1088/1755-1315/85/1/012067.

Lammarino, M., Taranto, D. A. \& Cristino, M. (2013). Endogenous levels of nitrites and nitrates in wide consumption foodstuffs: Results of five years of official controls and monitoring. Food chemistry, 140 (4), 763-771.

Parthasarathy, K. D. \& Bryan, S. N. (2012). Sodium nitrite: The "cure" for nitric oxide Insufficiency. Meat science, 92 (3), 274-279.

Parvizishad M., Dalvand A., Mahvi A. H. \& Goodarzi, F. (2017). A review of adverse effects and benefits of nitrate and nitrite in drinking water and food on human health. Health Scope. 2017; 6 (3), e14164. doi: 10.5812/jhealthscope. 14164.

Pengyan Z., Jay L., Guohua K., Yanyan L., Dan Y., Bo P. \& Yu Z. (2018). Disparity of nitrate and nitrite in vivo in cancer villages as compared to other areas in Huai River Basin, China. Science of the Total Environment, 612, 966-974.

Official Gazette of RS No 63. (2013). Regulation on the food additives.

Official Gazette of RS No 94. (2015). Regulation on the quality of ground meat, meat preparations and meat products.

Serbia. (2016). Statistical Office of the Republic of Serbia Bulletin Household budget survey.

Sindelar, J. J. \& Milkowski, L. A. (2012). Human safety controversies surrounding nitrate and nitrite in the diet. Nitric Oxide, 26 (4), 259-266.

ISO 2918. (1999). Meat and meat products - Determination of nitrite content.

Tomasevic, I., Dodevska, M., Simic, M., Raicevic, S., Matovic, V. \& Djekic, I. (2017). The use and control of nitrites in Serbian meat industry and the influence of mandatory HACCP implementation. Meat Science, 134, 76-78.

Zivkovic, D. \& Stajic, S. (2016). Meat preservation procedures. Meat technology 1, Faculty of Agriculture, University of Belgrade, Serbia. 